\title{
Residual Wastewater Treatment by an Aquatic Plant System in Tropical Area: Assessment of Arundo Donax and Pennisetum Purpureum Schumach
}

\author{
Mampuya Kinda Fidele*, and Philippe Audra \\ Polytech'Lab, UPR 7498, Polytech Nice Sophia, Université Côte d’Azur, 930 Route des Colles, 06903, Sophia Antipolis, France
}

*Corresponding author: Mampuya Kinda Fidele, Polytech'Lab, UPR 7498, Polytech Nice Sophia, Université Côte d’Azur, 930 Route des Colles, 06903, Sophia Antipolis, France; E-mail: mampuya-kinda.fidele@etu.univ-cotedazur.fr

Received: 02 Oct, 2020 | Accepted: 23 Nov, 2020 | Published: 30 Nov, 2020

Citation: Fidele MK, Audra P (2020) Residual Wastewater Treatment by an Aquatic Plant System in Tropical Area: Assessment of Arundo Donax and Pennisetum Purpureum Schumach. Int J Water Wastewater Treat 6(3): dx.doi.org/10.16966/2381-5299.177

Copyright: (C) 2020 Fidele MK, et al. This is an open-access article distributed under the terms of the Creative Commons Attribution License, which permits unrestricted use, distribution, and reproduction in any medium, provided the original author and source are credited.

\begin{abstract}
This study examines the potential of two local reed species (Arundo donax and Pennisetum purpureum Schumach) from Uíge province, Angola, to purify wastewater from the Kimpa Vita University Campus, under a vertical flow regime, and in a tropical climate. The assessment performance of these macrophytes is based on an experimental system with three plastic basins, with a capacity of $84 \mathrm{~L}$ each, containing a $0.25 \mathrm{~m}$-thick layer of gravel and topped with a layer of sand of $0.1 \mathrm{~m}$. The first basin is planted with Arundo donax, the second with Pennisetum $p$. Schumach, and the last is without vegetation cover. The obtained results show that the effluent treated by the planted filters has a better mineralization, with a satisfactory Chemical Demand for Oxygen (COD), unlike the unplanted filter. Indeed, the action of the roots and rhizomes allows a significant elimination of nutrients, although the average abatement in Biochemical Demand for Oxygen for five days $\left(B O D_{5}\right)$ of the whole system is low. In addition, the microbiological elimination of faecal coliforms is good on average and the effluents purified by these filters are clear and odorless. The planted filter of Arundo donax allows better elimination of Escherichia coli (E. coli) and enterococci compared to that of Pennisetum p. Schumach.
\end{abstract}

Keywords: Planted filter; Arundo donax; Pennisetum p. Schumach; wastewater; tropical climate; macrophytes

\section{Introduction}

The sanitation problem is still a concern in the world, with only 68 $\%$ of the world's population currently accessing basic facilities. Lowest rate is found in sub-Saharan Africa, as Angola is part [1]. Indeed, the sewerage networks in Angola are mainly unitary. They only exist in few cities, with extremely low coverage (Huambo, Namibe, Dundo and Saurimo). According to Vierra C [2], the national level produced $250 \mathrm{hm}^{3} /$ year of wastewater needed to be treated in 2012, and 381 $\mathrm{hm}^{3} /$ year of them was estimated for 2017. Consequently, the discharge of wastewater into the immediate environment makes it unfit for water consumption and causes human deaths and diseases. Only a few major cities $>350,000$ hab., such as Luanda, Benguela, Lobito have wastewater treatment systems [3]. Autonomous sanitation system, based on septic tanks, Ventilated Improved Pit (VIP) latrines, and sumps that do not provide adequate treatment for polluted water and excreta [4] should therefore be ignored. Since 2002, the Angolan government has invested in clean water and sanitation projects to achieve the 2030 Sustainable Development Goals [5]. However, efforts to install conventional sanitation and drinking water services in urban areas, even less in rural areas, remain a permanent threat to the population. The conventional treatment systems installed are too complex, inadequate, expensive, and become quickly inoperative [6]. Also, the lack of a sufficient number of qualified technicians and managers in this field, to ensure the maintenance of existing infrastructure, and the disproportion of the higher costs allocated to projects in urban areas compared to rural areas are among the causes of this dysfunction [5]. A review of the situation in West and Central Africa in 1993 (155 treatment identified plants), showed that conventional effluent treatment technics with activated muds and bacterial beds, accounted for $75 \%$ of the dysfunctional [7].

Today, macrophyte planted filters are considered as environmental options of wastewater treatment technics for sustainable development [8]. This notion of "Constructed Wetland" is rather new, but the concept is old, already used for sanitation in past times in Egypt and China. According to Brix H (1994) [9], several authors (Godfrey PJ, et al. [10], Athie D, et al. [11], Reddy KR, et al. [12], Cooper PF, et al. [13], Etnier C, et al. [14], Moshiri GA [15], Bavor HJ, et al. [16]), have confirmed their effectiveness in wastewater degradation. Such sanitation technics have also been experimented in Central and West Africa [17-20,6]. Such reliable, robust, and rustic wastewater treatment technology is adapted in non-collective and collective sanitation for small and medium-sized communities [50-2000 population equivalent (PE)] typical of tropical conditions [21]. The plants used in the planted filters are of different natures, and capable of degrading carbon and microbiological pollution. The use of local plants makes technology even more economical and adapted [6].

The objective of this work is to determine the potential of local plants in tropical areas to reduce carbon, bacteriological, and effluent 
nutrients from Kimpa Vita University (UNIKIVI) in an artificial wetland, and under a vertical flow regime. We compare the quality of the filtrate of a planted pilot system with Arundo donax and Pennisetum purpureum Schumach, respectively, to an unplanted pilot system. Then, from these results, we determine the most effective local macrophyte among the planted pilot system.

\section{Materials and Methods}

\section{Materials}

The study pilot is located at Kimpa Vita University, in the city of Uíge. This area has a warm and humid climate, with an average rainfall of $1,400 \mathrm{~mm}$, and a temperature between 18 and $32{ }^{\circ} \mathrm{C}$. The experimental device (Figure 1) consists of three plastic basins, with a capacity of $84 \mathrm{~L}$ each, filled with gravel of 4 to $8 \mathrm{~mm}$ of granulometry, on a thickness of $0.25 \mathrm{~m}$, and topped by a layer of $0.1 \mathrm{~m}$ of sand with $2.5 / 5 \mathrm{~mm}$ granulometry. One unplanted basin serves as a control $\left(\mathrm{B}_{\mathrm{R}}\right.$ : red basin) and the two others are planted with Pennisetum purpureum Schumach $\left(\mathrm{B}_{\mathrm{B}}\right.$ : blue basin), and Arundo donax ( $\mathrm{B}_{\mathrm{V}}$ : green basin), respectively, with a plant density of about $70 / \mathrm{m}^{2}$.

The pilots are fed by wastewater from the university campus, with a discharge of $20 \mathrm{L.j}^{-1}$ (October to November 2019), then $40 \mathrm{L.j}^{-1}$ (December to March 2020), with a regular weekly frequency. The flow percolates by gravity through the substrate. The filtrate is collected by a drain at the base of each basin, then discharged into an infiltration knot, located downstream to the pilots, equipped with a plant combination (Arundo donax, CyperusPapyrus, Typha latifolia, Cyperus Alternifolius), to improve the degradation of overflowing water and discharge of the filtration system. The tank that powers the pilots is a $22 \mathrm{~L}$ polyethylene can. The young shoots of both species of grasses used were collected from the natural environment.

\section{Hydraulic filter beds}

The hydraulic monitoring of the filtration system records the infiltration time of a water depth of $0.05 \mathrm{~m}$ of the raw effluent to drain and disappear from the surface of the substrate. The volume of water supplied during the residence time is also considered $\left(\mathrm{mL} \cdot \mathrm{min}^{-1}\right)$, and the amount of water lost by evapotranspiration during treatment, is expressed as a percentage, and calculated as follows [6]:

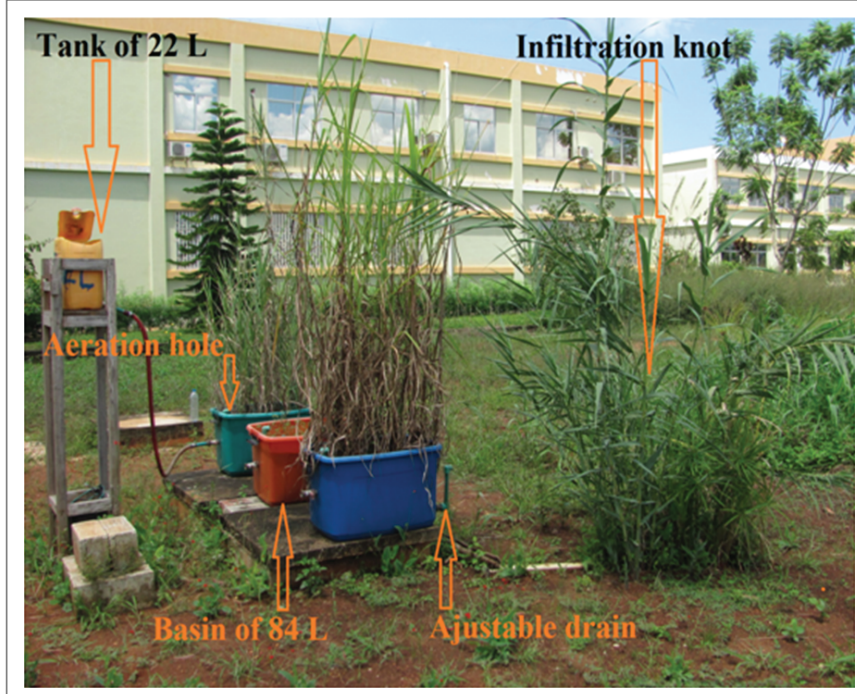

Figure 1: Experimental filtration design with local plants of Pennisetum p. Schumach and Arundo donax, Angola.

$$
Q=\frac{V_{e}}{t}
$$

Where, Q $\left(\mathrm{mL} \cdot \mathrm{min}^{-1}\right)$ is the infiltration flow, $\mathrm{V}$ is the volume of the effluent applied $(\mathrm{mL}), \mathrm{t}$ is the infiltration time $(\mathrm{min})$.

\section{Review of methods}

Determination of physical-chemical and microbiological parameters: Samples of raw and treated effluents were collected from the university campus and then sent to the approved laboratories of the Water and Sanitation Company of Uíge (Empresa de Água e Saneamento do Uíge-EASU) for physical analysis, and to AmbiÁfrica of Luanda for bacteriological analyses.

Temperature, Hydrogen Potential ( $\mathrm{pH}$ ), and Electrical Conductivity (EC) were determined on the spot using a MULTI-meter HANNA EDGE probe, HI 2020-02, and a HI 11310 Temperature Sensor. Suspended Materials (TSS) were determined by filtration of a volume of vacuum cellulosic filters, mesh $0.45 \mathrm{~m}$, in accordance with the French standard (AFNOR T90-105). The Chemical Demand For Oxygen (COD) was determined by the standard French method AFNOR T90101, using a HANNA Iris HI 801 spectrophotometer, by oxidation of the organic matter in the sample at $150{ }^{\circ} \mathrm{C}$ by excess of hot and acidic potassium dichromate, and then in the presence of silver sulphate. Excess potassium dichromate was dosed by colorimetry at $620 \mathrm{~nm}$. Kjeldahl Total Nitrogen (TKN) was determined by the AFNOR T90-110 method. Using the same HANNA HI 801 spectrophotometer, organic nitrogen was mineralized into ammonia nitrogen by sulphuric acid in the presence of a catalyst. Total Phosphorus (TP) was measured after acid mineralization and potassium persulfate, followed by an analysis of orthophosphates (AFNOR T90-023). The five-day Biochemical Oxygen Demand $\left(\mathrm{DBO}_{5}\right)$ was determined by the Manometric method based on the Warburg principle (AFNOR T90-103). The research and counting of total coliforms, E. coli and enterococci were conducted using IDEXX Colilert-18 and Quanti-Tray (ISO 9308-2) methods.

Samples: The samples were collected twice a month over a period of 4 months (October 2019 to March 2020) as follows: a sample of raw water collected at the outlet of the tank supplying the three pilots, followed by three samples of treated water collected after one day at the outlet of these same filters, and finally, three more after 7 days. Of the 56 samples collected, 616 analyses were conducted at the rate of 11 analyses per sample, or $66.7 \%$ of the initially scheduled analyses, due to travel restrictions during the COVID-19 pandemic.

Statistical analysis: The preparation and statistical processing of the data (results of analyses of the physical and microbiological samples) were carried out using Excel (Microsoft 365) and using IBM SPSS Statistics software, version 20.

The physical-chemical data was tested for normality. Microbiological counts were undergone a logarithmic transformation to get closer to normality. These analyses showed that the physical-chemical concentrations and microbiological parameters of the treated effluent are not normal and not homogeneous. The use of non-parametric tests revealed non-significant and differences between filter samples, for the pair comparison of the filter pairs, approved by Kruskal-Wallis test. The hypothesis $\mathrm{H}_{0}$ is equality between distributions, and the threshold of significance is $\mathrm{p}>0.05$. 


\section{Results}

\section{Characteristics of raw effluent}

The raw effluent of UNIKIVI presents average measured values, basic trend $(\mathrm{pH}=7.86)$ and shows it is biodegradable $\left(\mathrm{COD} / \mathrm{BOD}_{5}=1.56<3\right)$ (Appendix 1) [22]. Conventional parameters are shown on the table 1.

\section{Hydraulic filters}

The hydraulic flow of Arundo donax (750 to $389 \mathrm{~mL} \cdot \mathrm{min}^{-1}$ ), although higher than that of the planted filter of Pennisetum p. Schumach (656 to $438 \mathrm{~mL}^{\mathrm{min}}{ }^{-1}$ ), decreased at the beginning of the experiment (early October to early November), then quickly rose again in midNovember for the $B_{B}$ planted filter, and in early December for the planted filter $B_{v}$ (Figure 2). Out of a total of $240 \mathrm{~L}$ of water supplied to each filter during the testing period, the average volume of water lost in the planted $\mathrm{B}_{\mathrm{V}}$ filter is $88.3 \mathrm{~L}(36.8 \%)$, in the planted $\mathrm{B}_{\mathrm{B}}$ filter is 83.1L (34.6\%), and in the unplanted $B_{R}$ filter $46.1 \mathrm{~L}(19.2 \%)$. Vegetal planted filters had a reduced infiltration time of 15 to $16 \mathrm{mn}$ (an improvement in percolation time from 18.9 to $24.5 \%$ ) due to the root and rhizomatous development of macrophytes (Table 2). In November 2019 , the $B_{v}$ planted filter did not return any volume of water. This loss is related to the evapotranspiration phenomenon, which implied to

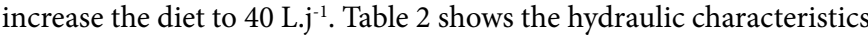
of the different filters.

\section{Treatment performances of pilots}

Raw effluent recorded temperatures ranging from 18 to 26.6 ${ }^{\circ} \mathrm{C}$, with an average of $22.9{ }^{\circ} \mathrm{C}$ at the entrance of the filters. For the treated effluent, the temperature was $24{ }^{\circ} \mathrm{C}$ after $24 \mathrm{~h}$ and dropped to $23{ }^{\circ} \mathrm{C}$ after a week. The $\mathrm{pH}$ has a basic trend, with an average of 7.9. The $\mathrm{pH}$ of the planted filters remained stable at 7.4, while that of the unplanted $B_{R}$ filter rose to 8.1 after 1 week. However, by November 2019 , the unplanted filter has shown a pH of 9.6 after one week, an average increase of 2 units; this is explained by the presence of soap in the effluent originating from cleaning products and of weeds (algae).

The conductivity of the raw effluent fluctuated between 1,024 and $406 \mu \mathrm{S} . \mathrm{cm}^{-1}$, decreasing with each treatment in the unplanted $B_{R}$ filter, with an average of $610 \mu \mathrm{S} . \mathrm{cm}^{-1}$ (Figure 3). This behaviour is similar to that observed at the beginning of the operation of the $B_{B}$ and $B_{v}$ planted filters (October 2019).

Table 1: Characteristics of raw effluent of Kimpa Vita University $(n=56)$.

\begin{tabular}{|c|c|c|c|}
\hline Parameters & $\begin{array}{c}\text { Maximum } \\
\text { values }\end{array}$ & $\begin{array}{c}\text { Minimum } \\
\text { values }\end{array}$ & $\begin{array}{c}\text { Average values } \\
\pm \sigma\end{array}$ \\
\hline $\mathrm{pH}$ & 8.66 & 7.46 & $7.86 \pm 0.38$ \\
\hline Temperature $\left({ }^{\circ} \mathrm{C}\right)$ & 26.6 & 18 & $22.86 \pm 3.16$ \\
\hline $\mathrm{EC}\left(\mu \mathrm{S} . \mathrm{cm}^{-1}\right)$ & 1024 & 406 & $\begin{array}{c}609.88 \pm \\
250.02\end{array}$ \\
\hline $\operatorname{COD}\left(\mathrm{mg} \cdot \mathrm{L}^{-1}\right)$ & 1220 & 100 & $\begin{array}{c}375.25 \pm \\
260.02\end{array}$ \\
\hline $\mathrm{BOD}_{5}\left(\mathrm{mg} \cdot \mathrm{L}^{-1}\right)$ & 413 & 164 & $240.13 \pm 96.03$ \\
\hline $\operatorname{TSS}\left(\mathrm{mg} \cdot \mathrm{L}^{-1}\right)$ & 648 & 35 & $316.84 \pm 199.06$ \\
\hline TKN (mg. L $\left.^{-1}\right)$ & 141 & 10 & $53.1 \pm 43.21$ \\
\hline TP $\left(m g . \mathrm{L}^{-1}\right)$ & 45 & 1 & $16.0 \pm 14.82$ \\
\hline Total coliforms (UFC.100 mL $\mathrm{mL}^{-1}$ ) & $>2420$ & $>2420$ & $>2420 \pm 0$ \\
\hline Escherichia coli (UFC.100 mL ${ }^{-1}$ ) & $>2420$ & $>2420$ & $>2420 \pm 0$ \\
\hline Enterococci (UFC.100 mL ${ }^{-1}$ ) & $>2420$ & 437 & $2090 \pm 809.56$ \\
\hline
\end{tabular}

The average TSS concentration of the raw effluent fluctuates between 35 and $684 \mathrm{mg} . \mathrm{L}^{-1}$. The $\mathrm{B}_{\mathrm{R}}$ unplanted filter provided an average removal of $83-85 \%$ during the two periods of residence, compared to the other two planted filters, with an average TSS concentration of 31 to $25 \mathrm{mg} \cdot \mathrm{L}^{-1}$. The $\mathrm{B}_{\mathrm{v}}$ planted filter showed a reduction of $-14 \%$ in 24 $\mathrm{h}$ in mid-February 2020, and then improved by $14 \%$ after one week. This is due to the quality of the raw effluent, less rich in organic matter and extremely basic ( $\mathrm{pH}=8.66$, always $\geq 8$ ). The peaks of TSS observed in December 2019 and February 2020 at the raw effluent correspond to an increase in student numbers during the end-of-year exams and entrance competition period (Figure 4). However, the concentration in the filters remained extremely low, ranging from 27.5 to $25 \mathrm{mg} . \mathrm{L}^{-}$ ${ }^{1}$. Planted filters improved by up to $83 \%$ of TSS removal after one week of treatment. However, in terms of the concentration and TSS retentions of the filtrates (paired samples, signed Kruskal Wallis test, threshold of significance $\mathrm{p}>0.05$ ), statistical analysis showed no significant difference between the three filtration systems, regardless of the residence time.

For COD, the average concentration of the raw effluent at the entrance of the filtration system greatly varies with an average of 375 mg.L. ${ }^{-1}$. The November 2019 peak at 1,220 mg.L $L^{-1}$ (more than $69 \%$ of COD compared to average), is the result of overload caused by the increase of students on campus (Figure 5). The $B_{R}$ unplanted filter had an average removal rate of $83 \%$ in COD after $24 \mathrm{~h}$, and then increased to $91 \%$ after one week. The Kruskal-Wallis test shows a significant difference $(p<0.05)$ in the COD removal between the $B_{R}$ filter and the two planted filters $\left(B_{B}\right.$ and $B_{V}$ of $\left.24 \mathrm{~h}\right)$ after one week of treatment. However, planted filters showed a marked $81 \%$ improvement in COD reduction after one week of treatment.

For $\mathrm{BOD}_{5}$, the average raw effluent concentration is $240.1 \mathrm{mg} \cdot \mathrm{L}^{-1}$. All filters had an average $\mathrm{BOD}_{5}$ removal in $24 \mathrm{~h}<50 \%$ and recorded negative performance in $\mathrm{DBO}_{5}$ reaching $-27 \%$ for the $\mathrm{B}_{\mathrm{B}}$ planted filter after $24 \mathrm{~h}$, and $-40 \%$ after one week. Statistical analysis shows no significant difference (Kruskal-Wallis test, $\mathrm{p}>0.05$ ) between the three $\mathrm{BOD}_{5}$ treatment systems, regardless of the treatment period, however the $\mathrm{B}_{\mathrm{v}}$ planted filter significantly improved its performance to $54 \%$ after one week of residence.

The average TKN concentration of the raw effluent is $53.1 \mathrm{mg} \cdot \mathrm{L}^{-1}$. On the other hand, the TKN concentration of the filtrate of planted filter $\mathrm{B}_{\mathrm{B}}$ is low ( 9 to $4 \mathrm{mg} \cdot \mathrm{L}^{-1}$ ), with a reduction of 83 to $93 \%$, higher than that of the control unplanted filter, during the 2 periods of

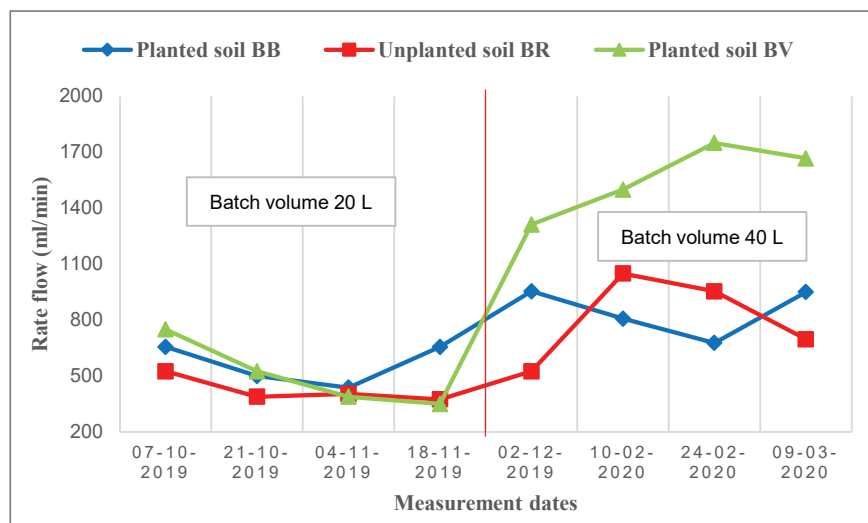

Figure 2: Time evolution of average flow of raw effluent from planted filter of Arundo donax $\left(\mathrm{B}_{\mathrm{v}}\right)$, Pennisetum $p$. Schumacher $\left(\mathrm{B}_{\mathrm{B}}\right)$ and of unplanted filter $\left(B_{R}\right)$. 


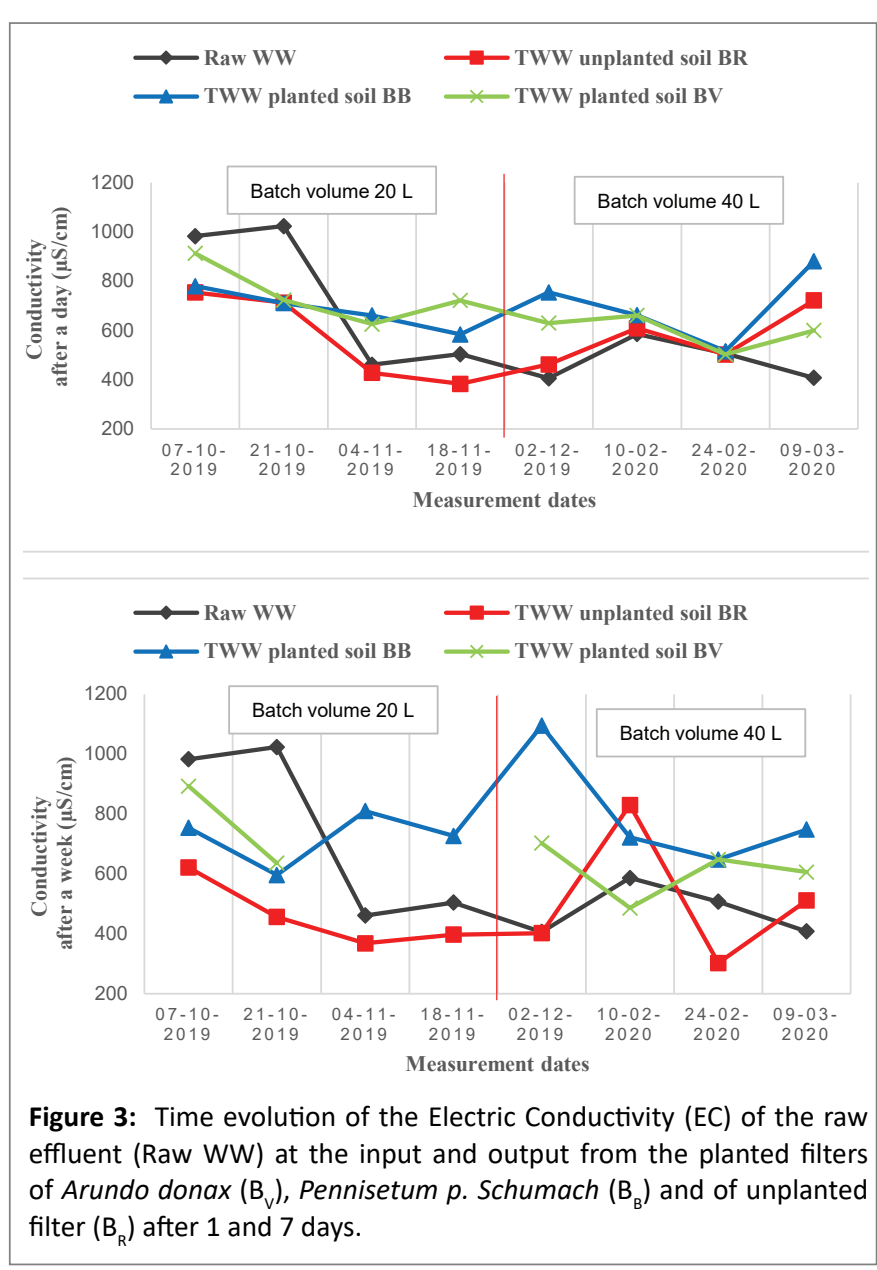

residence (Figure 6). In addition, a successive negative retention of $-19 \%$ and $-21 \%$ of the $B_{R}$ unplanted filter was observed in early December 2019 for both treatment periods. A small significant difference (approved Kruskal Wallis test, $\mathrm{p}<0.05$ ) was observed for the planted filter $\left(B_{V}\right)$ and the unplanted filter $\left(24-h B_{R}\right)$ after one week of residence. The average concentration of the raw effluent in Total Phosphorus (TP) being less charged at the inlet of the filtration systems, fluctuated from 0.9 to $44.8 \mathrm{mg} . \mathrm{L}^{-1}$, with a near-zero TP filtrate concentration at the outlet of the three filters (Figure 6). Planted filters showed a better average TP removal that ranged from 91 to $99 \%$ in both periods, and therefore no significant difference was observed between the three pilots (Kruskal-Wallis test, $\mathrm{p}>0.05$ ).

The raw effluent at the entrance of the filtration systems has an average $>2,420$ UFC. $100 \mathrm{~m} . \mathrm{L}^{-1}$ of total coliforms. During the two periods of residence, the filtrates of these three filters did not record a large decrease in total coliform concentration and their average removal remained below $50 \%$.

For Escherichia-coli, the number of colonies of raw effluent and 24 -h filtrates for the three filters is $>2,420$ UFC. $100 \mathrm{~m} . \mathrm{L}^{-1}$. The $\mathrm{B}_{\mathrm{v}}$ planted filter has a better $E$-coli reduction of $98 \%$, against $68 \%$ for the control filter, after one week of residence (Figure 7), according to the variance analysis (Kruskal-Wallis test, $\mathrm{p}<0.05$ ), between the planted filter of Arundo donax $\left(\mathrm{B}_{\mathrm{V}}\right)$ and the other three filters $\left(24-\mathrm{h} \mathrm{B}_{\mathrm{R}}, \mathrm{B}_{\mathrm{B}}\right.$ and $\mathrm{B}_{\mathrm{V}}$ ) for a period of one week.

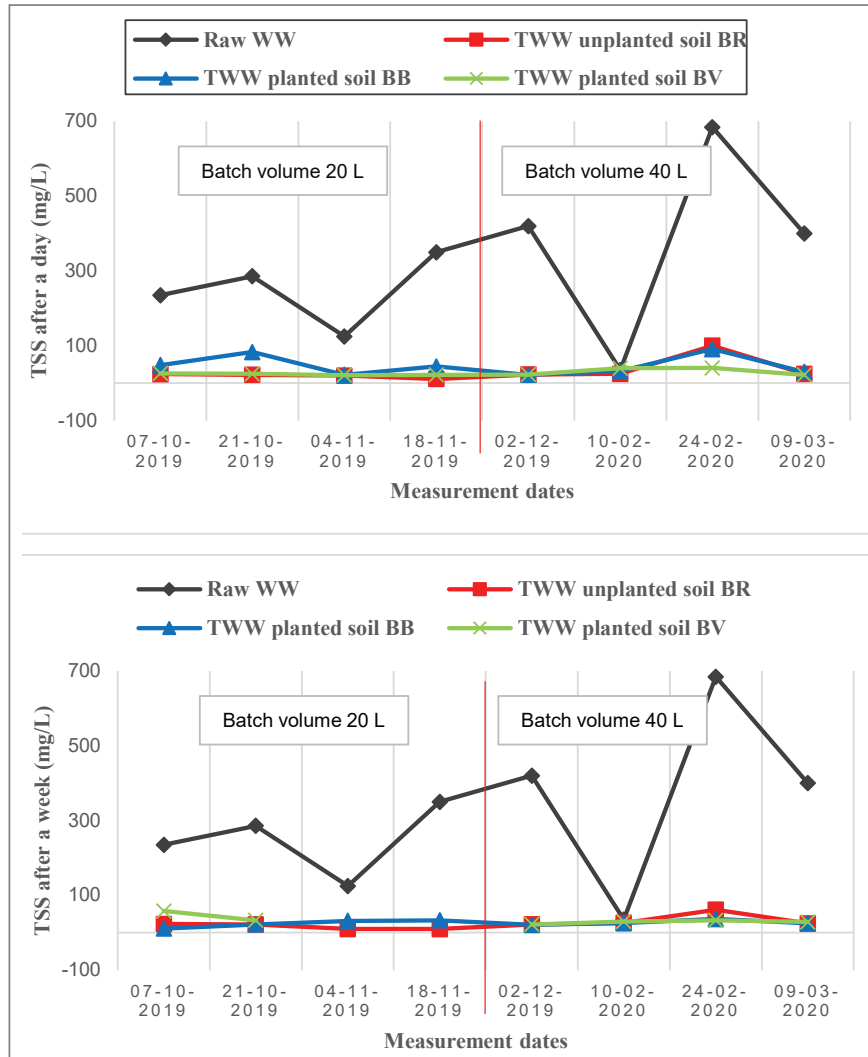

Figure 4: Time evolution of the Total Suspended Solids (TSS) of the raw effluent (Raw WW) at the input and output from the planted filters of Arundo donax $\left(\mathrm{B}_{v}\right)$, Pennisetum p. Schumach $\left(\mathrm{B}_{\mathrm{B}}\right)$ and of unplanted filter $\left(B_{R}\right)$ after 1 and 7 days.

For enterococci, the raw effluent and the $\mathrm{B}_{\mathrm{v}}$ planted filter had respectively an average concentration of 1,757 UFC.100 m.L $\mathrm{L}^{-1}$ and an average removal of $93 \%$ after one week of residence (Figure 7). However, overloads were observed in February 2020 at the unplanted $B_{R}$ filter $(-111 \%)$ after $24 \mathrm{~h}$, and $B_{B}$ planted filter $(-26 \%)$ after a week. Indeed, the unplanted $B_{R}$ filter received 437 UFC. $100 \mathrm{~m} \cdot \mathrm{L}^{-1}$ of enterococci from the raw effluent and released 921 UCF. 100 m. $\mathrm{L}^{-1}$ after $24 \mathrm{~h}$. The $\mathrm{B}_{\mathrm{B}}$ planted filter pulled out $550 \mathrm{UFC} .100 \mathrm{~m} \cdot \mathrm{L}^{-1}$ after a week. Statistical analysis confirmed a significant difference in enterococci elimination between the $B_{V}$ planted filter and the other two filters (24$h B_{R}$ and $B_{V}$ ) after one-week of residence (Kruskal-Wallis test, $p<0.05$ ).

\section{Real removal}

The apparent removal rate calculated above does not consider the precipitation or the evapotranspiration that occurred during the test period. These may eventually change the volume of effluent in the filtration system. Considering this change in volume, treatment outcomes could improve, and therefore can be calculated with the actual (or absolute) removal of the filter $[18,23]$ :

Actual removal efficiency $=\frac{C h \text { arge at the entrance }- \text { Charge at the outlet }}{C h \text { arge at the inlet }} \times 100$

Where the load at the entrance $(\mathrm{g})=$ concentration $\left(\mathrm{g} . \mathrm{L}^{-1}\right)$ * volume of raw water brought to the filter $(\mathrm{L})$, and the load at the outlet $(\mathrm{g})=$ concentration $\left(\mathrm{g} . \mathrm{L}^{-1}\right)$ * returned volume $(\mathrm{L})$, at the outlet of each system. 

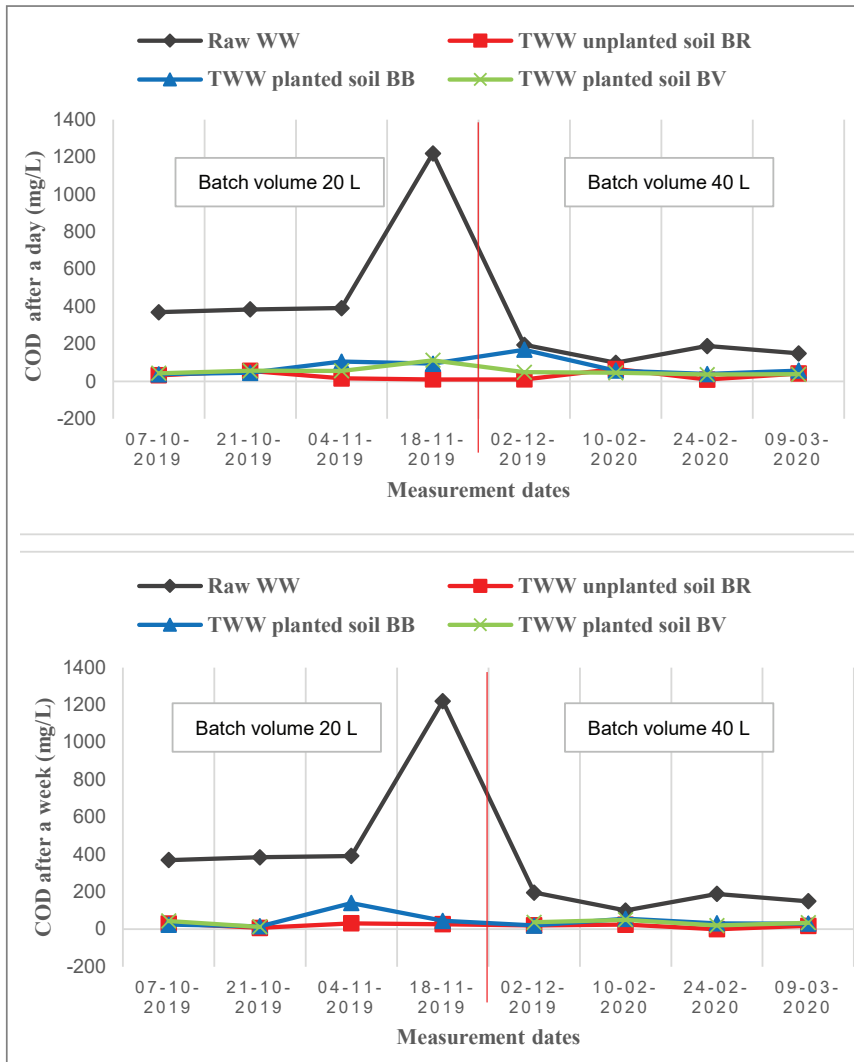

Figure 5: Time evolution in COD content of the raw effluent (Raw $\mathrm{WW}$ ) at the inlet and outlet of the planted filters of Arundo donax $\left(\mathrm{B}_{\mathrm{v}}\right)$, Pennisetum p. Schumach $\left(B_{B}\right)$ and unplanted filter $\left(B_{R}\right)$ after 1 and 7 days.

Planted filters showed a slight degradation in organic load in both periods of residence, except for $B_{B}$ planted filter TSS which increased by $2 \%$ after one week of residence. Nutrients improved as TKN increased to an average of $20 \%$ in $24 \mathrm{~h}$ and $12 \%$ in 7 days, while TP increased by $4 \%$ in $24 \mathrm{~h}$, and remained stable at $99 \%$ in 7 days. Bacteriological treatment improved by an average of $17 \%$ for enterococci, 13 to 16 $\%$ for faecal and total coliforms for a $24 \mathrm{~h}$ of residence. After a week's residence, the filter removal planted $B_{B}$ deteriorated, but that of the $B_{v}$ planted filter improved by 13 to $25 \%$. Figure 8 represents the actual removal of the three UNIKIVI effluent filtration systems.

\section{Discussion}

The biodegradability of wastewater from the Kimpa Vita University Campus, filtered through the three pilots, provided a good removal of carbon pollution and nutrients. The 30 -min peak of infiltration time experienced by the $\mathrm{B}_{\mathrm{v}}$ planted filter in mid-November 2019 is due to a $320 \mathrm{~mm}$ rainfall, and to the low temperatures $\left(22.5-23{ }^{\circ} \mathrm{C}\right)$ that increased the density of rhizomes. Note that the cool weather also increased the moisture level of the substrates and the viscosity of the effluent, which leads the water depth to take a longer time to percolate through the substrates. The switch from 20 to $40 \mathrm{L.j}^{-1}$ minimized the effect of evapotranspiration with the $\mathrm{B}_{\mathrm{v}}$ planted filter for a one-week treatment residence. The average temperature of the raw effluent fluctuated by $\pm 1{ }^{\circ} \mathrm{C}$ relative to that of the filters during the two periods of residence; this is simply due to the freshness of the soil, favoured by the presence of plants that protect the surface of filters [7]. However, the increase of infiltration time for the unplanted filter can be clearly observed in table 2, implying a decrease in the infiltration rate. This is due to the saturation of coarse and fine materials blocking the pores of filtering mass through which the raw effluent passes. Indeed, the stems of the plants contained in the planted filters, could pierce the clogging layer, and open free spaces for the flow around it. This allows them to infiltrate a large volume of water [24]. As a result, the hydraulic flow of the $\mathrm{B}_{\mathrm{v}}$ planted filter is $66 \%$, higher than that of the unplanted filter. This allows treating a larger volume of effluent, or to reduce the area per inhabitant equivalent needed. The mechanical role of the reeds ensured the non-clogging of the planted filters.

Figure 3 shows that the average $\mathrm{EC}$ of $\mathrm{B}_{\mathrm{B}}$ and $\mathrm{B}_{\mathrm{V}}$ planted filter filtrates $\left(763\right.$ and $\left.672 \mu \mathrm{S} . \mathrm{cm}^{-1}\right)$ is higher than that of the unplanted filter $\left(486 \mu \mathrm{S} . \mathrm{cm}^{-1}\right)$ and that of raw effluent $\left(610 \mu \mathrm{S} . \mathrm{cm}^{-1}\right)$. A similar result was obtained by Mandi L, et al. [18] and Brix H [25] using rooted "Arundo donax" for the treatment of urban wastewater, in which they attributed the increase in EC to the presence of reeds. In addition, during their studies for a Typha latifolia plantation, Finlayson and Chick (1983) associated this increase to the phenomenon of vegetation evapotranspiration that tends to concentrate effluent. Likewise, Ranjani, et al. [26], linked this increase to soil mineral leaching and to the mineralization of organic matter. However, the EC of the $B_{R}$ unplanted filter decreases in relation to the raw effluent concentration. Results are similar to that of Tanner CC, et al. [27] cited by Achack M, et al. [23], which observed the reduction in EC of the effluent treated in a gravel bed planted with Schoenoplectus validus when the residence time increases. The weekly alternation of supplying and resting times of the filters ensured the aeration of the unsaturated area and the mineralization of the filters. According to Achak M, et al. [23], the sun exposition during drying times allows the soil tightening and thus restoring its infiltration properties. Figure 2 illustrates the $B_{R}$ unplanted filter flow duplication (mid-December 2019 to mid-February 2020).

During this study, there was a half-unit $\mathrm{pH}$ decrease for planted filters, from an average of 7.9 for raw wastewater to 7.4 for filters. This acidification of the filters may be due to the oxidation of nitric acid $\mathrm{NH}_{4}^{+}$or COD [6]. According to Tanner CC, et al. [27] mentioned by Achak M, et al. [23], a similar result was observed with a slight decrease in $\mathrm{pH}$ from 7.2 for raw effluent to about 6.6 to 7 for the treated effluent in a gravel filter of Schoenoplectus Validus with submerged flow.

In general, compared to raw effluent, the planted filter of Arundo donax $\left(\mathrm{B}_{\mathrm{v}}\right)$ showed significant improvement (40-99\%) of the physical-chemical removal, providing a sufficient residence time occurred (Figure 5). Indeed, the removal of carbon pollution by the $\mathrm{B}_{\mathrm{v}}$ planted filter was particularly efficient (79\%- $80 \%$ COD) during the two treatment periods with 4 to $11 \%$ more retention, compared to the $B_{R}$ unplanted filter. The decrease in COD levels in filters from different filters is due to the physical retention of coarse materials on the filter surface and finer materials passing through the pores, and the oxidation of effluent by microbial flora. Hydraulic retention time is reduced (15 to $20 \mathrm{~min}$ ) (Table 2), due to the thin layer of sand that does not allow a good retention of TSS and the removal of the COD, but also to the presence of roots and rhizomes of plants that increase the rate of infiltration and allow to accepting hydraulic overload [28].

In addition, the control filter has a 5 to $2 \%$ decrease in TSS compared to planted filters, with the rate ranging from 83 to $85 \%$. This reduction in TSS is due to the filtration and sedimentation of coarse and fine solid waste on the filter surface, forming a sludge deposit that must be scraped from time to time. In addition, it has been found that the filtrates with vegetation cover are clear and odourless, which is a good 

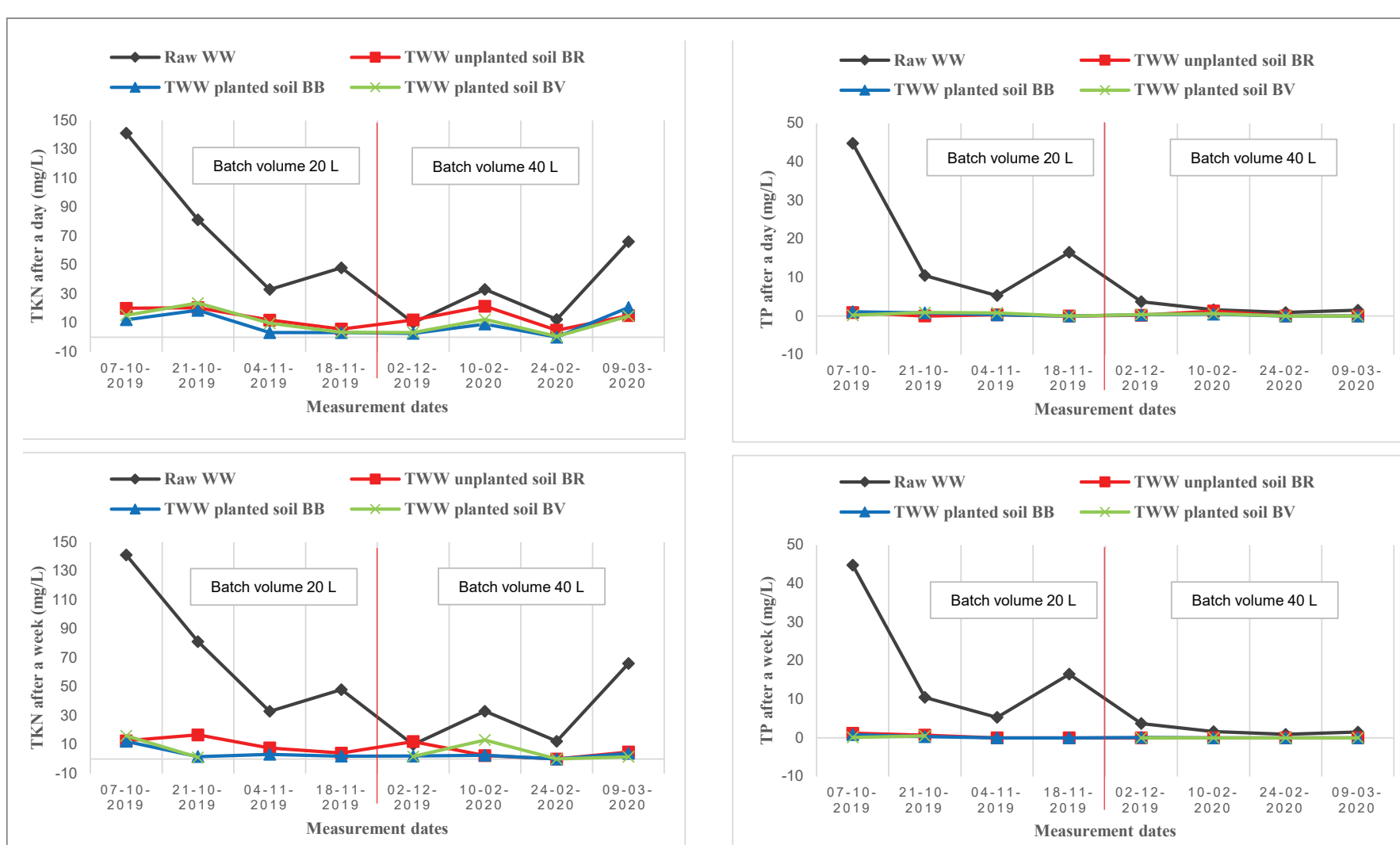

Figure 6: Time evolution of raw effluent nutrients (EU Brut) at the inlet and outlet of planted filters of Arundo donax ( $\mathrm{B}_{\mathrm{v}}$ ), Pennisetum $p$. Schumach $\left(B_{B}\right)$ and unplanted filter $\left(B_{R}\right)$ after 1 and 7 days.

Table 2: Hydraulic characteristics of planted and unplanted filters.

\begin{tabular}{|l|c|c|c|c|}
\hline \multicolumn{1}{|c|}{ Infiltration system } & $\begin{array}{c}\text { Average } \\
\text { infiltration } \\
\text { time (min) }\end{array}$ & $\begin{array}{c}\text { Average } \\
\text { returned } \\
\text { volume (L) }\end{array}$ & $\begin{array}{c}\text { Average } \\
\text { rate flow } \\
\text { (mL.min }^{-1} \text { ) }\end{array}$ & $\begin{array}{c}\text { Average } \\
\text { volume } \\
\text { lost (L) }\end{array}$ \\
\hline $\begin{array}{l}\mathrm{B}_{\mathrm{B}} \text { (planted soil of } \\
\text { Pennisetum p. Sch.) }\end{array}$ & 15,9 & $\begin{array}{c}156,9 \\
(65,4 \%)\end{array}$ & 705 & $\begin{array}{c}83,1 \\
(34,6 \%)\end{array}$ \\
\hline $\mathrm{B}_{\mathrm{R}}$ (unplanted soil) & 19,6 & $\begin{array}{c}193,9 \\
(80,8 \%)\end{array}$ & 614,9 & $\begin{array}{c}46,1 \\
(19,2 \%)\end{array}$ \\
\hline $\begin{array}{l}\mathrm{B}_{\mathrm{V}} \text { (planted soil of } \\
\text { Arundo donax) }\end{array}$ & 14,8 & $\begin{array}{c}151,7 \\
(63,2 \%)\end{array}$ & 1030,4 & $\begin{array}{c}88,3 \\
(36,8 \%)\end{array}$ \\
\hline
\end{tabular}

qualitative indicator of the functioning of the system, on the contrary to the raw effluent.

For nutrients, planted filters had an TKN removal rate of 78-83\% in $24 \mathrm{~h}$ for the entire system, then improving from 88 to $93 \%$ after 7 days, while for the control filter, the rate remained limited at $75 \%$. According to Ouattara JMP, et al. [6], this result is due to the biological oxidation of nitric acid by nitrifying bacteria and to the assimilation by plants. The unplanted $B_{R}$ filter had negative performance of $-19 \%$ and $-21 \%$ during both treatment periods. These negative values are probably due to TKN overload in the filter without vegetation cover. Having received a raw water content of $10 \mathrm{mg} . \mathrm{L}^{-1}$, the filter released $11.9 \mathrm{mg}$. $\mathrm{L}^{-1}$ after $24 \mathrm{~h}$, and $12.1 \mathrm{mg} . \mathrm{L}^{-1}$ after a week. It is worth noting the increasing value in $\mathrm{TKN}$ at the outlet of the unplanted $\mathrm{B}_{\mathrm{R}}$ filter. A similar result was found by Mandi L, et al. [18], in their study on the use of reeds for urban wastewater treatment. These authors attributed the removal of $-17 \%$ ammonium of the unplanted filter, to the overload of the ammonium effluent at the filter output. In addition, the removal rate little fluctuated for TP, but remained acceptable for three systems for both periods and reached $99 \%$ after 7 days. According to Brix $\mathrm{H}$ [25], this efficiency of TKN and TP removal is due to the increase in the EC. Similarly, Wathugala AG, et al. [29], cited by Mandi L, et al. [18], also achieved results close to $100 \%$ TP reduction for Phragmites Australis. The $\mathrm{BOD}_{5}$ elimination rate remained below $50 \%$ in $24 \mathrm{~h}$. All three systems recorded negative performances that were explained by the basification of the filters filtering massif, degrading their biological performance. Nevertheless, the planted filter of Arundo donax improved in one week upto a $54 \%$ removal rate.

From a bacteriological point of view, the planted filter of Arundo donax $\left(\mathrm{B}_{\mathrm{v}}\right)$ generally showed a better removal compared to the unplanted $B_{R}$ filter. The latter had considerably improved (7-98 \%) compared to the raw effluent, providing a sufficient residence time occurred. Indeed, the $\mathrm{B}_{\mathrm{v}}$ planted filter had a significant $98 \%$ reduction in E. coli after 7 days. In a similar study, Ouattara JMP, et al. [6] achieved $98 \%$ and $90 \%$ E. coli removal results for a plant cover filter and control filter, respectively. Finally, for Enterococci, the planted filter of Pennisetum p. Schumach $\left(\mathrm{B}_{\mathrm{B}}\right)$ provided a $67 \%$ removal, while the Arundo donax planted filter $\left(\mathrm{B}_{\mathrm{v}}\right)$ excelled up to $93 \%$. These results are probably due to the action of root exudates secreted by Arundo donax and Pennisetum p. Schumach, which may have a bactericidal effect (Table 3 and 4) [30]. 


\section{Conclusion}

The study of the experimental pilot at the University Campus Kimpa Vita of Uíge, Angola, highlighted the potential of local reeds (Arundo donax and Pennisetum p. Schumach), to eliminate nutrients ( $95 \%$ TKN and $99 \% \mathrm{TP}$ ), thanks to the action of roots and rhizomes. Although sand performance in the elimination of organic pollution for the $B_{R}$ unplanted filter is $93 \%$ in COD and $87 \%$ in TSS, vegetation cover filters have improved by up to $87 \%$ in COD and $89 \%$ in TSS. The average unplanted filter $\mathrm{BOD}_{5}$ abatement is low but is increased to 71 $\%$ for the planted Arundo donax $\left(\mathrm{B}_{\mathrm{v}}\right)$ filter. Although microbiological removal for the same planted filter is on average $99 \%$ for faecal coliforms, and $96 \%$ for enterococci, total coliforms removal is $67 \%$ satisfactory after one week in the filter.

Based on these results, we can confirm the effectiveness of filters planted with reeds in purifying domestic wastewater. The Arundo donax delivers better hydraulic flow $\left(1,030 \mathrm{~mL} \cdot \mathrm{min}^{-1}\right)$ and a higher capacity to withstand flooding, compared to the Pennisetum purpureum Schumach (705 mL.min ${ }^{-1}$ ). The physical properties of these pilots in the elimination of carbon pollution (COD and TSS) can still be improved by increasing the thickness of the filtering massif (sand $\geq 0.30 \mathrm{~m}$ ). For treatments beyond $24 \mathrm{~h}$, biological conditions can also be improved by placing a breathing tube above the saturation zone, producing a coexistence of aerobic and anoxic conditions $[31,28]$.

\section{Appendices}

\section{Appendix 1}

Table 3: Summary of the physical and microbiological analyses carried out on the inlet and outlet samples of the planted filters $B_{B}, B_{v}$ and unplanted filter $B_{R}$ for a residence time of $24 h(a, b, c)$ and a week $(d, e, f)$; with $n$ : the number of data; Max: maximum value; Min: minimum value; Moy: average value; $\sigma$ standard deviation.

(a) Hydraulic residence time=1 day; ( $n=56) ; B_{R}$ (unplanted soil)

\begin{tabular}{|l|c|c|c|c|c|c|c|c|}
\hline Parameters & \multicolumn{3}{|c|}{ Filtrated wastewaters (mg/L) } & \multicolumn{5}{|c|}{ Abatement (\%) } \\
\hline & Max & Moy & Min & $\sigma$ & Max & Moy & Min & $\sigma$ \\
\hline COD & 67 & 31 & 10 & 22 & 99 & 83 & 33 & 22 \\
\hline BOD $_{5}$ & 180 & 130 & 83 & 32 & 77 & 37 & -10 & 29 \\
\hline TSS & 100 & 31 & 11 & 28 & 97 & 83 & 29 & 22 \\
\hline TKN & 21 & 14 & 5 & 7 & 88 & 59 & -19 & 36 \\
\hline TP & 1 & 0,3 & 0 & 0,7 & 100 & 88 & 19 & 28 \\
\hline Total Coliforms & 2420 & 2420 & 2420 & 0 & 0 & 0 & 0 & 0 \\
\hline Escherichia-coli & 2420 & 2153 & 816 & 655 & 66 & 11 & 0 & 27 \\
\hline Enterococci & 2420 & 987 & 93 & 912 & 96 & 30 & -111 & 79 \\
\hline
\end{tabular}

(b) Hydraulic residence time=1 day; $(n=56) ; B_{B}$ (planted soil of Pennisetum p. Schumach)

\begin{tabular}{|l|c|c|c|c|c|c|c|c|}
\hline Parameters & \multicolumn{3}{|c|}{ Filtrated wastewaters (mg/L) } & \multicolumn{4}{c|}{ Abatement (\%) } \\
\hline & Max & Moy & Min & $\sigma$ & Max & Moy & Min & $\sigma$ \\
\hline COD & 170 & 76 & 38 & 45 & 92 & 67 & 13 & 28 \\
\hline BOD $_{5}$ & 293 & 153 & 77 & 63 & 79 & 27 & -27 & 36 \\
\hline TSS & 91 & 47 & 22 & 27 & 95 & 75 & 9 & 28 \\
\hline TKN & 21 & 9 & 0 & 8 & 100 & 83 & 69 & 12 \\
\hline TP & 1 & 0,4 & 0 & 0,6 & 100 & 93 & 69 & 10 \\
\hline Total coliforms & 2420 & 2420 & 2420 & 0 & 0 & 0 & 0 & 0 \\
\hline Escherichia-coli & 2420 & 2180 & 980 & 588 & 59 & 10 & 0 & 24 \\
\hline Enterococci & 2420 & 981 & 31 & 1130 & 94 & 58 & 0 & 46 \\
\hline
\end{tabular}

(c) Hydraulic residence time=1 day; $(n=56) ; B_{v}$ (planted soil of Arundo donax)

\begin{tabular}{|l|c|c|c|c|c|c|c|c|}
\hline \multirow{2}{*}{ Parameters } & \multicolumn{4}{|c|}{$\begin{array}{c}\text { Filtrated wastewaters } \\
\text { (mg/L) }\end{array}$} & \multicolumn{4}{c|}{ Abatement (\%) } \\
\hline & Max & Moy & Min & $\sigma$ & Max & Moy & Min & $\sigma$ \\
\hline COD & 113 & 55 & 37 & 25 & 91 & 79 & 54 & 12 \\
\hline BOD $_{5}$ & 209 & 123 & 74 & 48 & 82 & 40 & -23 & 34 \\
\hline TSS & 41 & 28 & 21 & 8 & 95 & 78 & -14 & 38 \\
\hline TKN & 24 & 10 & 1 & 8 & 96 & 78 & 63 & 13 \\
\hline TP & 1 & 0,4 & 0 & 0,5 & 100 & 91 & 63 & 13 \\
\hline Total coliforms & 2420 & 2022 & 33 & 974 & 99 & 16 & 0 & 40 \\
\hline Escherichia-coli & 2420 & 2252 & 1414 & 411 & 42 & 7 & 0 & 17 \\
\hline Enterococci & 2420 & 1351 & 205 & 1173 & 90 & 38 & 0 & 43 \\
\hline
\end{tabular}

(d) Hydraulic residence time $=7$ days; $(n=54) ; B_{R}$ (unplanted soil)

\begin{tabular}{|l|c|c|c|c|c|c|c|c|}
\hline \multirow{2}{*}{ Parameters } & \multicolumn{3}{|c|}{$\begin{array}{c}\text { Filtrated wastewaters } \\
\text { (mg/L) }\end{array}$} & \multicolumn{4}{c|}{ Abatement (\%) } \\
\hline & Max & Moy & Min & $\sigma$ & Max & Moy & Min & $\sigma$ \\
\hline COD & 32 & 20 & 0 & 11 & 100 & 91 & 75 & 8 \\
\hline BOD $_{5}$ & 288 & 127 & 42 & 87 & 83 & 44 & -20 & 37 \\
\hline TSSS & 62 & 25 & 10 & 16 & 97 & 85 & 25 & 24 \\
\hline TKN & 17 & 8 & 0 & 6 & 100 & 75 & -21 & 40 \\
\hline TP & 1 & 0,2 & 0 & 0,6 & 100 & 99 & 93 & 2 \\
\hline Total coliforms & 2420 & 1623 & 548 & 899 & 77 & 33 & 0 & 37 \\
\hline Escherichia-coli & 2420 & 770 & 32 & 1118 & 99 & 68 & 0 & 46 \\
\hline Enterococci & 1986 & 469 & 1 & 778 & 100 & 80 & 18 & 32 \\
\hline
\end{tabular}

(e)

(e) Hydraulic residence time $=7$ days; $(n=54) ; B_{B}$ (planted soil of Pennisetum $p$. Schumach)

\begin{tabular}{|l|c|c|c|c|c|c|c|c|}
\hline \multirow{2}{*}{ Parameters } & \multicolumn{4}{|c|}{$\begin{array}{c}\text { Filtrated wastewaters } \\
\text { (mg/L) }\end{array}$} & \multicolumn{4}{c|}{ Abatement (\%) } \\
\hline & Max & Moy & Min & $\sigma$ & Max & Moy & Min & $\sigma$ \\
\hline COD & 140 & 46 & 16 & 40 & 96 & 81 & 44 & 18 \\
\hline BOD $_{5}$ & 263 & 147 & 57 & 82 & 79 & 33 & -40 & 43 \\
\hline TSS & 37 & 26 & 11 & 8 & 95 & 83 & 27 & 24 \\
\hline TKN & 12 & 4 & 0 & 4 & 100 & 93 & 79 & 6 \\
\hline TP & 1 & 0,2 & 0 & 0,4 & 100 & 99 & 97 & 1 \\
\hline Total coliforms & 2420 & 2023 & 35 & 974 & 99 & 16 & 0 & 40 \\
\hline Escherichia-coli & 2420 & 1291 & 30 & 1244 & 99 & 47 & 0 & 51 \\
\hline Enterococci & 2420 & 754 & 173 & 836 & 93 & 52 & -26 & 51 \\
\hline
\end{tabular}

\begin{tabular}{|c|c|c|c|c|c|c|c|c|}
\hline \multicolumn{9}{|c|}{ Arc } \\
\hline \multirow[t]{2}{*}{ Parameters } & \multicolumn{4}{|c|}{$\begin{array}{l}\text { Filtrated wastewaters } \\
\qquad(\mathrm{mg} / \mathrm{L})\end{array}$} & \multicolumn{4}{|c|}{ Abatement (\%) } \\
\hline & Max & Moy & Min & $\sigma$ & Max & Moy & Min & $\sigma$ \\
\hline COD & 51 & 33 & 13 & 14 & 97 & 80 & 49 & 17 \\
\hline BOD $_{5}$ & 214 & 93 & 35 & 64 & 79 & 54 & 7 & 28 \\
\hline TSS & 58 & 34 & 22 & 12 & 95 & 77 & 14 & 32 \\
\hline TKN & 16 & 6 & 0 & 7 & 100 & 88 & 60 & 15 \\
\hline TP & 1 & 0,1 & 0 & 0,3 & 100 & 99 & 95 & 2 \\
\hline Total coliforms & 2420 & 1883 & 272 & 1074 & 89 & 22 & 0 & 44 \\
\hline Escherichia-coli & 73 & 40 & 8 & 31 & 100 & 98 & 97 & 1 \\
\hline Enterococci & 491 & 166 & 1 & 228 & 100 & 93 & 80 & 9 \\
\hline
\end{tabular}




\section{Appendix 2}

Table 4: Actual removal of UNIKIVI effluent in planted and unplanted filters after $24 \mathrm{~h}$ and 7 days; $\mathrm{B}_{\mathrm{B}}$ : planted filter of Pennisetum purpureum Schumach; $\mathrm{B}_{\mathrm{v}}$ : planted filter of Arundo donax; $\mathrm{B}_{\mathrm{R}}$ : unplanted filter.

\begin{tabular}{|c|c|c|c|c|c|c|c|c|}
\hline Retention (\%) after a day & COD & TSS & $\mathrm{BOD}_{5}$ & TKN & TP & Total coliforms & Escherichia coli & Enterococci \\
\hline $\mathrm{B}_{\mathrm{v}}$ planted soil of Arundo donax & 87 & 86 & 62 & 86 & 94 & 47 & 41 & 61 \\
\hline$B_{R:}$ unplanted soil & 86 & 86 & 49 & 66 & 90 & 19 & 28 & 44 \\
\hline Improvement (\%) & -1 & 0 & 13 & 20 & 4 & 28 & 13 & 17 \\
\hline $\begin{array}{l}\text { B planted soil of Pennisetum } p . \\
\text { Schumach }\end{array}$ & 79 & 84 & 52 & 89 & 95 & 35 & 41 & 73 \\
\hline$B_{R:}$ unplanted soil & 86 & 86 & 49 & 66 & 90 & 19 & 28 & 44 \\
\hline Improvement (\%) & -7 & -2 & 3 & 23 & 5 & 16 & 13 & 29 \\
\hline
\end{tabular}

\begin{tabular}{|c|c|c|c|c|c|c|c|c|}
\hline Retention (\%) after 7 days & DCO & MES & $\mathrm{DBO}_{5}$ & TKN & TP & Total coliforms & Escherichia coli & Enterococci \\
\hline $\mathrm{B}_{\mathrm{v}}$ planted soil of Arundo donax & 87 & 85 & 71 & 92 & 99 & 67 & 99 & 96 \\
\hline$B_{R:}$ unplanted soil & 93 & 87 & 55 & 80 & 99 & 46 & 74 & 83 \\
\hline Improvement (\%) & -6 & -2 & 16 & 12 & 0 & 21 & 25 & 13 \\
\hline $\begin{array}{l}\text { B planted soil of Pennisetum p. } \\
\text { Schumach }\end{array}$ & 87 & 89 & 56 & 95 & 99 & 45 & 65 & 68 \\
\hline $\mathrm{B}_{\mathrm{R}:}$ unplanted soil & 93 & 87 & 55 & 80 & 99 & 46 & 74 & 83 \\
\hline Improvement (\%) & -6 & 2 & 1 & 15 & 0 & -1 & -9 & -15 \\
\hline
\end{tabular}

Average abatement for $24 \mathrm{~h}$ of planted and unplanted filters
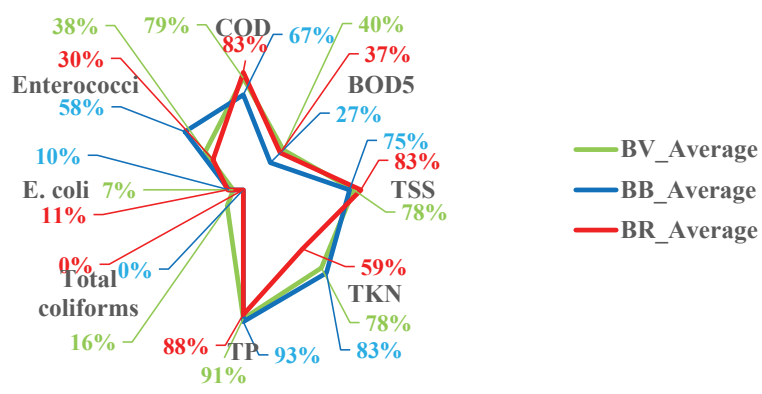

Average abatement for 7 days of planted and unplanted filters
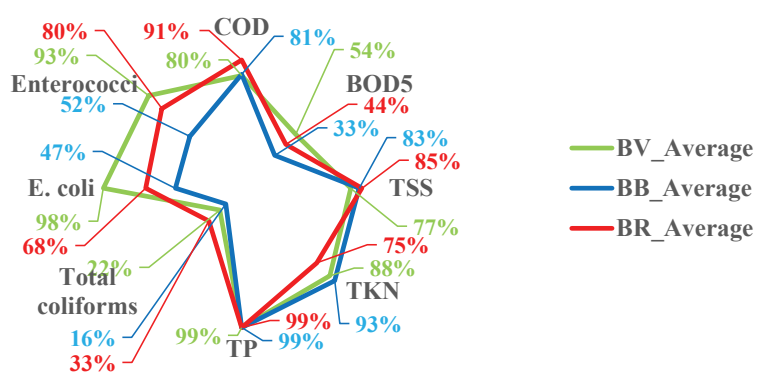

Figure 7: Summary of the average abatements measured on the samples in the inlet and outlet from the Arundo donax planted filter $\left(B_{v}\right)$, Pennisetum $p$. Schumach planted filter $\left(B_{B}\right)$, and unplanted filter $\left(B_{R}\right)$.

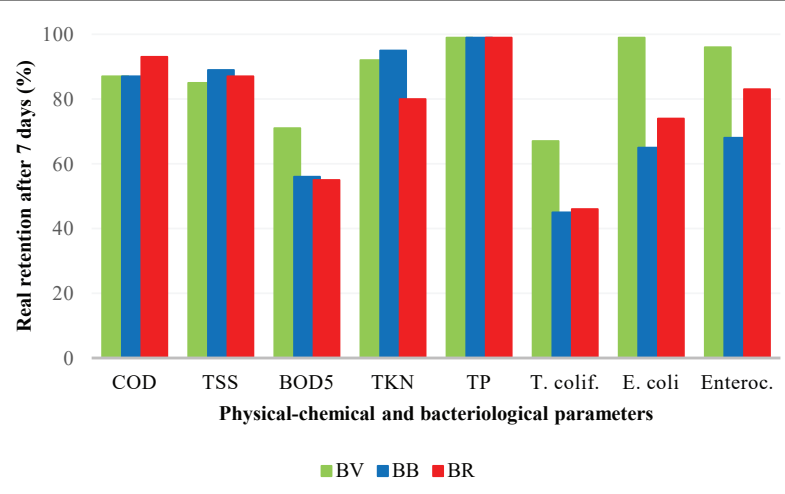

Figure 8: Actual reduction in planted filters of Arundo donax $\left(\mathrm{B}_{\mathrm{v}}\right)$ and Pennisetum p. Schumach $\left(B_{B}\right)$, and unplanted filter $\left(B_{R}\right)$ in $24 h$, and one week (details in appendix 2).

\section{References}

1. WHO, UNICEF (2017) Progress on drinking water, sanitation, and hygiene: 2017 Update and SDG Baselines. Geneva.

2. Vierra C (2013) Águaglobal: Cluster da água Angola. A internacionalização do sector portugues da água: Porto: Associação Empresarial de Portugal.

3. Vierra C, Ferraz N, Roques S (2014) Cluster da água Angola. Uma estratégia colectiva: Manual de boas práticas. Porto: Associação Empresarial de Portugal.

4. Kone M, Bonou L, Koulidiati J, Joly P, Sodre S (2012) Percolation sur sable et sur substrat de coco. Revue des Sciences de l’Eau 25: 139151.

5. UNICEF A, ADRA A (2016) Água e saneamento em Angola no Orçamento Geral do Estado (OGE).

Citation: Fidele MK, Audra P (2020) Residual Wastewater Treatment by an Aquatic Plant System in Tropical Area: Assessment of Arundo Donax and Pennisetum Purpureum Schumach. Int J Water Wastewater Treat 6(3): dx.doi.org/10.16966/2381-5299.177 
6. Ouattara JMP, Coulibaly L, Manizan PN, Gourène G (2008) Traitement des eaux résiduaires urbaines par un marais Artificiel à drainage vertical planté avec panicum maximum sous climat tropical. Eur $\mathrm{J}$ Sci Res 23: 25-40.

7. Kone $D$ (2002) Épuration des eaux usées par lagunage à microphytes et à macrophytes en Afrique de l'ouest et du centre: État des lieux, performances épuratoires et critères de dimensionnement. École Polytechnique Fédérale de Lausanne.

8. Dotro G, Langergraber G, Molle P, Nivala J, Puigagut J, et al. (2017) Treatment wetlands- Biological Wastewater Treatment Series. Volume 7 London: IWA Publishing.

9. Brix H (1994) Use of constructed wetlands in water pollution control: Historical development, Present status, and future perspectives. Water Sci Technol 30: 209-223.

10. Godfrey PJ, Kaynor ER, Benforado J (1985) Ecological considerations in wetlands treatment of municipal wastewaters. United States.

11. Athie D, Cerri CC (1987) The use of macrophytes in water pollution control. Water Sci Technol 19: 177.

12. Reddy KR, Smith WH (1987) Aquatic plants for water treatment and resource recovery. Magnolia Publishing.

13. Cooper PF, Findlater BC (1990) Constructed wetlands in water pollution control. $1^{\text {st }}$ Edition- Proceedings of the international conference on the use of constructed wetlands in water pollution control. Pergamon, UK.

14. Etnire C, Guterstam B (1991) Ecological engineering for wastewater treatment. Proceedings for the international conference at Stensund folk college, Sweden $1^{\text {st }}$ Edition. Gothenburg, Sweden

15. Moshiri GA (1993) Constructed wetlands for water quality improvement. Lewis Publishers, Florida.

16. Bavor HJ, Mitchell DS (1994) Wetland Systems in Water Pollution Control. Water Sci Tech 29: 336

17. Mandi L, Houhoum B, Asmama S, Schwrtzbrod J (1996) Wastewater treatment by reed beds: an experimental approach. Wat Res 30 : 2009-2016.

18. Abbisy M, Mandi L (1999) Utilisation des plantes aquatiques enracinées pour le traitement des eaux usées urbaines: Cas du roseau. J Water Sci 12: 285-315.

19. Mashauri DA, Mulungu DMM, Abdulhussein BS (2000) Constructed wetland at the university of Dar es Salaam. Wat Res 34: 1135-1144.
20. Semadi $F$ (2010) Faisabilté du traitement des eaux d'un Oued chargé en éléments traces métalliques (ETM) par filtres plantés de macrophytes (Phragmites Australis): cas de l'Oued MeboudjaAnnaba- Algérie. Annaba: 228.

21. Boutin C, Liénard A, Lesavre J (2000) Filières d'épuration pour petites collectivités: Les cultures fixées sur supports fins. Ingénieries- EAT: 3-13.

22. Bourrier R, Satin M, Selmi B (2017) Guide technique de l'assainissement. $5^{\text {th }}$ Edition. Éditions Le Moniteur, Paris.

23. Achak M, Ouazzani N, Mandi L (2011) Élimination des polluants organiques des effluents de l'industrie oléicole par combinaison d'un filtre àsable etun lit planté. Revue des Sciences de l'Eau 24: 35-51.

24. Liénard A, Molle P, Boutin C, Dodane PH (2005) Traitement des eaux usées par marais artificiels: Action des plantes et développement de la technique en France. TSM numéro 11: 45-56.

25. Brix H (1987) Treatment of wastewater in the rhizosphere of wetland plants. The root-zone method. Water Sci Technol 19: 107-118.

26. Ranjani K, Kneidinge CH, Rios R, Salinas N, Soto G, et al. (1996) Treatment of maize processing industry wastewater by constructed wetlands. Volume 1- Dans Proceedings of $5^{\text {th }}$ International Conference on wetlands systems for water pollution control, Austria.

27. Tanner CC, Clayton JS, Upsdell MP (1995) Effect of loading rate and planting on treatment of dairy farm wastewater in constructed wetlands. I. Removal of oxygen demand, Suspended solids and Faecal coliforms. Water Res 29: 17-26.

28. Molle P, Liénard A, Boutin C, Merlin G, Iwema A (2004) Traitement des eaux usées domestiques par marais artificiels : État de l'art et performances des filtres plantés de roseaux en France. Ingénieries numéro spé: $23-32$

29. Wathugala AG, Suzuki T, Kurihara Y (1987) Removal of nitrogen, phosphorus and COD from wastewater using sand filtration system with Phragmites Australis. Water Res 21: 1217-1224.

30. Ennabili A (2008) Épuration extensive des eaux usées en zones touristiques méditerranéennes (Nord-Ouest Du Maroc). Revue AFN Maroc: $37-49$.

31. Latune RL, Molle P (2017) Les filtres plantés de végétaux pour le traitement des eaux usées domestiques en milieu tropical. Guide de dimensionnement de la filière tropicalisée. Agence française Pour La biodiversité, Guides et protocoles: 1-76. 